\title{
Integration of Seed Biopriming, Soil and Foliar Application of Formulations of Trichoderma Species for Growth Promotion of Sorghum under Field Condition
}

\author{
Nazia Manzar ${ }^{1,2 *}$ and Yogendra Singh ${ }^{1}$ \\ ${ }^{1}$ Department of Plant Pathology, Govind Ballabh Pant University of Agriculture and \\ Technology, Pantnagar, Uttarakhand, India \\ ${ }^{2}$ ICAR-National Bureau of Agriculturally Important Microorganisms (ICAR-NBAIM), \\ Kushmaur, Mau Nath Bhanjan, Uttar Pradesh, India \\ *Corresponding author
}

\section{A B S T R A C T}

\section{Keywords}

Seed biopriming, Soil application with biocontrol enriched FYM, Trichoderma, Sorghum

Article Info

Accepted:

20 May 2019

Available Online:

10 June 2019
Seed biopriming, soil application with enriched FYM and foliar application of talc based formulation of Trichoderma isolates were evaluated under field condition during the Kharif season 2015. Integration of seed biopriming, soil application enriched FYM and foliar application of Trichoderma isolates T3 and T19 was found highly effective in promoting root and shoot length and stem diameter of sorghum. Individually, soil application and biopriming of seed with Trichoderma isolates were effective in growth promotion activity but their effectiveness was greater when applied as a combination. Thus, combined application of the formulations is recommended for the growth promotion activity in sorghum crop.

\section{Introduction}

Sorghum is grown in more than 90 countries and ranked as 5th most important cereal crop worldwide. It is a staple food in Africa and provides diet for 500 millions of people. Sorghum is used as fodder crop to feed the cattle as well as used for industrial purposes. Although Sorghum can tolerate adverse conditions but its yield as well as overall plant health is hampered by abiotic and biotic stresses (Chala et al., 2011). Trichoderma has been used as biocontrol agent against many phytopathogenic fungi and Trichoderma spp are also reported to promote plant health by improving overall plant growth aside from the direct inhibition of plant pathogens (AbdelFattah et al., 2007).

The present work was planned to assess the abilities of Trichoderma isolates as well as to check the efficiency of combined application 
of the formulation for the growth promotion of sorghum under field conditions.

\section{Materials and Methods}

Isolates of T3, T4, T15 and T19 of Trichoderma asperallum and T6 isolate of Trichoderma harzianum isolated from sorghum rhizosphere of Uttarakhand were used for field evaluation.

\section{Field Trials}

The field experiment was conducted in Randomized block design with five replications in Kharif Season 2015. Susceptible Sorghum cultivar PC-23 was planted at sorghum pathology block, Livestock Research Centre, GBPUA\&T for evaluation of effectiveness of growth promoting activity of Trichoderma isolates.

\section{Seed biopriming}

Seed were presoaked in water for $24 \mathrm{hrs}$. Presoaked seeds were treated with talc based product of Trichoderma having $10^{8} \mathrm{cfu} / \mathrm{g}$ @ $10 \mathrm{~g} / \mathrm{kg}$ of seeds in $2 \%$ gum arabic solution. The seed were incubated for $48 \mathrm{~h}$ at 25 $28^{\circ} \mathrm{C}$.Trichoderma isolates adhered on the seed; grow on the seed surface to form a protective layer all around the seed coat under moist condition. The observation regarding root length, shoot length and stem diameter were recorded after 90DAS.

\section{Soil application}

For the soil application the $20 \mathrm{~kg}$ of talc based formulation of $T$. asperallum and $T$. harzianum isolates was mixed with $200 \mathrm{~kg}$ of well-rotted Farm yard manure in a pit and covered for 10 days by polythene sheet. The mixture was turned every 3 days regularly. When Trichoderma mycelium proliferated throughout the FYM then on 10th of day pit was opened and mixture was turned well and spread in the field plots one week before sowing.

\section{Foliar spray}

Foliar spray of talc based formulation Trichoderma isolates @ 10g/lit of water was given after 30 DAS.

\section{Results and Discussion}

Effect of biopriming of seed with different isolates of Trichoderma on growth promotion of sorghum

The data presented in table 1 , shows the effect of biopriming of seed with different isolates of Trichoderma on root length, shoot length and stem diameter of sorghum plants.

\section{Root length}

The data shows that after 90DAS, significant increase in root length was recorded in biopriming of seed with different Trichoderma isolates viz: T3, T19, T4, T6, and T15 as compared to control. Among the treatments, the highest root length was recorded in T3 isolate $(44.254 \mathrm{~cm})$ however, T19 $(44.080 \mathrm{~cm})$ was at par with T3 followed by $\mathrm{T} 4(40.974 \mathrm{~cm})$ isolate whereas least growth was observed in untreated control $(36.288 \mathrm{~cm})$.

\section{Shoot length}

The data shows that after 90DAS, seed biopriming with different Trichoderma isolates viz: T3, T19, T4, T6, and T15 significantly increased the shoot length as compared to control. The highest shoot length was recorded in T3 isolate $(293.000 \mathrm{~cm})$ followed by T19 isolate $(287.000 \mathrm{~cm})$ however which T4 $(285.200 \mathrm{~cm})$ and T6 $(281.000 \mathrm{~cm})$ isolate was statistically at par 
with T19, whereas least growth was observed in untreated control $(253.000 \mathrm{~cm})$.

\section{Stem diameter}

Seed biopriming with different isolates of Trichoderma significantly increased the stem diameter. Highest stem diameter was observed in $\mathrm{T} 3$ isolate $(2.030 \mathrm{~cm})$ however, T19 isolate $(1.958 \mathrm{~cm})$ was statistically at par with $\mathrm{T} 3$, followed by $\mathrm{T} 4$ isolate $(1.818 \mathrm{~cm})$ and least growth was observed in untreated control $(1.476 \mathrm{~cm})$.

Our results are similar to that reported by Yadav et al., (2013) who concluded that seed biopriming enhanced germination percentage and increased plant growth as compared to non-primed control plants. Seed biopriming reduces the amount of biocontrol agent that is used for biopriming than seed coating or seed treatment. Seed biopriming also enhanced the uniform and rapid seedling emergence. The bioprimed seed tolerate the adverse soil conditions and promote the plant growth (Mathre et al., 1999). Biopriming of seed enhanced the seedling growth and reduced the incidence of seed and soil borne diseases (Zaidi et al., 2004).

Mastauri et al., (2010) concluded that biopriming of seed with biocontrol agents enhanced the plant vigour and seed germination percentage of sorghum seeds than untreated sorghum seed. Seed biopriming with formulation of Trichoderma significantly increased the plant growth promotion (Singh and Nautiyal, 2012). Ousley et al., (1994) reported similar finding in petunia plants where they observed that the application of $T$. harzianum strain TH1 applied at a rate of $0.1 \% \mathrm{w} / \mathrm{v}$ significantly increased the root and shoot length as compared to control. Harman et al., (2000) observed that biopriming of seed with strain T22 (T.harzianum) significantly increased the root and shoot length of maize under field and glass house conditions.

\section{Effect of soil application of Trichoderma isolates enriched FYM on growth promotion activity of Sorghum}

The data presented in table 2 , shows that soil application of Trichoderma isolates T3, T19, T4, T6, and T15 enriched FYM significantly increased the root length, shoot length and stem diameter of sorghum plants as compared to control after 90DAS.

\section{Root length}

Maximum root length was recorded in $\mathrm{T} 3$ isolate $(42.904 \mathrm{~cm})$ which was statistically at par with T19 isolate $(42.092 \mathrm{~cm})$ followed by T4 isolate $(40.886 \mathrm{~cm})$ isolate whereas least root length was found in untreated control $(36.288 \mathrm{~cm})$.

\section{Shoot length}

Maximum shoot length was observed in T3 $(280.400 \mathrm{~cm})$ isolate however T19 $(279.600 \mathrm{~cm})$ isolate was statistically at par with T3 isolate followed by T4 $(271.000 \mathrm{~cm})$ isolate whereas least shoot length was found in untreated control $(253.000 \mathrm{~cm})$.

\section{Stem diameter}

Highest stem diameter was observed in T19 $(1.838 \mathrm{~cm})$ isolate however, T3 $(1.752 \mathrm{~cm})$ isolate was statistically at par with T19 followed by $\mathrm{T} 4(1.572 \mathrm{~cm})$ isolate whereas least shoot length was found T6 isolate $(1.334 \mathrm{~cm})$.

Soil application of Trichoderma viride and Trichoderma harzianum enriched FYM one week before sowing of seed was more effective in reducing the wilt and root rot of chickpea and enhanced the plant growth. 
Table.1 Effect of biopriming of seed with different isolates of Trichoderma on growth promotion of sorghum

\begin{tabular}{|l|r|r|r|}
\hline Treatments & Root length $(\mathbf{c m})$ & Shoot length $(\mathbf{c m})$ & \multicolumn{1}{l|}{$\begin{array}{l}\text { Stem diameter } \\
(\mathbf{c m})\end{array}$} \\
\hline T3 & $44.254 \pm 1.716^{\mathrm{a}}$ & $293.000 \pm 5.385^{\mathrm{a}}$ & $2.030 \pm 0.036^{\mathrm{a}}$ \\
\hline T4 & $40.974 \pm 0.912 \mathrm{~b}^{\mathrm{ab}}$ & $285.200 \pm 7.003^{\mathrm{ab}}$ & $1.818 \pm 0.031^{\mathrm{b}}$ \\
\hline T6 & $40.526 \pm 0.866^{\mathrm{b}}$ & $281.000 \pm 6.782^{\mathrm{ab}}$ & $1.768 \pm 0.036^{\mathrm{b}}$ \\
\hline T15(A) & $39.186 \pm 0.859^{\mathrm{bc}}$ & $273.000 \pm 5.385^{\mathrm{b}}$ & $1.620 \pm 0.031^{\mathrm{c}}$ \\
\hline T19(B) & $44.080 \pm 1.263^{\mathrm{a}}$ & $287.000 \pm 3.742^{\mathrm{ab}}$ & $1.958 \pm 0.038^{\mathrm{a}}$ \\
\hline Control & $36.288 \pm 0.889^{\mathrm{c}}$ & $253.000 \pm 4.899^{\mathrm{c}}$ & $1.476 \pm 0.059^{\mathrm{d}}$ \\
\hline CD at 5\% & 1.713 & 7.244 & 0.089 \\
\hline C.V. & 3.153 & 1.957 & 3.770 \\
\hline SE(m) & 0.577 & 2.439 & 0.030 \\
\hline $\begin{array}{l}\text { Values given in column are the average of five replications. Values with } \\
\text { different alphabetical }(\mathrm{a}-\mathrm{d}) \text { superscripts within a column are significantly } \\
\text { different (P } \leq \text { 0.05) using Duncan's multiple range tests (DMRT). }\end{array}$ \\
\hline
\end{tabular}

Table.2 Effect of soil application of Trichoderma isolates enriched FYM on growth promotion of Sorghum

\begin{tabular}{|l|c|c|c|}
\hline Treatment & Root length (cm) & Shoot length $(\mathbf{c m})$ & $\begin{array}{c}\text { Stem diameter } \\
(\mathbf{c m})\end{array}$ \\
\hline T3 & $42.904 \pm 0.859^{\mathrm{a}}$ & $280.400 \pm 4.285^{\mathrm{a}}$ & $1.752 \pm 0.034^{\mathrm{a}}$ \\
\hline T4 & $40.886 \pm 0.688^{\mathrm{bc}}$ & $271.000 \pm 2.793^{\mathrm{ab}}$ & $1.572 \pm 0.036^{\mathrm{b}}$ \\
\hline T6 & $39.294 \pm 0.312^{\mathrm{cd}}$ & $266.400 \pm 4.750^{\mathrm{ab}}$ & $1.334 \pm 0.038^{\mathrm{c}}$ \\
\hline T15 & $37.962 \pm 0.485^{\mathrm{d}}$ & $261.800 \pm 6.061^{\mathrm{b}}$ & $1.394 \pm 0.044^{\mathrm{c}}$ \\
\hline T19 & $42.092 \pm 0.452^{\mathrm{ab}}$ & $279.600 \pm 4.226^{\mathrm{a}}$ & $1.838 \pm 0.018^{\mathrm{a}}$ \\
\hline Control & $36.288 \pm 0.889^{\mathrm{d}}$ & $253.000 \pm 4.899^{\mathrm{c}}$ & $1.476 \pm 0.059^{\mathrm{ab}}$ \\
\hline C.D. at 5\% & 1.575 & 8.826 & 0.106 \\
\hline SE(m) & 0.530 & 2.971 & 0.036 \\
\hline C.V. & 2.971 & 2.472 & 5.125 \\
\hline $\begin{array}{l}\text { Values given in column are the average of five replications. Values with different alphabetical } \\
\text { (a-d) superscripts within a column are significantly different (P } \leq 0.05)\end{array}$ \\
multiple range tests (DMRT).
\end{tabular}


Table.3 Effect of seed bioprimimg + soil application + foliar spraying with Trichoderma isolates on growth promotion of sorghum

\begin{tabular}{|c|c|c|c|}
\hline Treatment & Root length (cm) & Shoot length $(\mathrm{cm})$ & $\begin{array}{l}\text { Stem diameter } \\
(\mathrm{cm})\end{array}$ \\
\hline T3 & $53.124 \pm 0.337^{\mathrm{a}}$ & $324.8 \pm 3.338^{\mathrm{a}}$ & $2.172 \pm 0.032^{\mathrm{a}}$ \\
\hline T4 & $50.852 \pm 0.580^{b}$ & $306.8 \pm 3.891^{b}$ & $1.658 \pm 0.026^{b}$ \\
\hline T6 & $50.460 \pm 0.455^{b}$ & $304.0 \pm 1.817^{b}$ & $1.636 \pm 0.028^{b}$ \\
\hline T15 & $50.730 \pm 0.546^{b}$ & $305.0 \pm 2.881^{b}$ & $1.712 \pm 0.009^{b}$ \\
\hline T19 & $53.248 \pm 0.264^{\mathrm{a}}$ & $326.2 \pm 2.059^{\mathrm{a}}$ & $2.106 \pm 0.035^{\mathrm{a}}$ \\
\hline Control & $36.288 \pm 0.889^{c}$ & $253.000 \pm 4.899^{c}$ & $1.476 \pm 0.059^{c}$ \\
\hline C.D.at5\% & 1.465 & 10.241 & 0.106 \\
\hline $\mathrm{SE}(\mathrm{m})$ & 0.493 & 3.447 & 0.036 \\
\hline C.V. & 2.244 & 2.541 & 4.433 \\
\hline \multicolumn{4}{|c|}{$\begin{array}{l}\text { Values given in column are the average of five replications. Values witl } \\
\text { different alphabetical }(\mathrm{a}-\mathrm{c}) \text { superscripts within a column are significantly } \\
\text { different }(\mathrm{P} \leq 0.05) \text { using Duncan's multiple range tests (DMRT). }\end{array}$} \\
\hline
\end{tabular}

Enhancement in the Trichoderma population, played a positive role in increasing the uptake of nutrients from the rhizospheric zone that ultimately enhanced the plant growth promotion after the soil application of Trichoderma enriched FYM has been reported in Maize (Bjurkman et al.,1994), tomato (Ozbay et al., 2004), pea (Naseby et al., 2000) and cucumber (Kleifield and Chet, 1992). Maximum rhizospheric colonization and growth promotion was recorded in terms of number of tillers, rootlets, root and shoot length and number of grain per spike in wheat crop after the soil application of Trichoderma harzianum enriched FYM (Sharma et al., 2012). Soil application of Trichoderma enriched FYM was effective in controlling the seed borne pathogenic fungi $R$. solani, $F$. moniliforme, $F$. oxysporum, $F$. solani, $A$. alternata and B. theobromae (Mustafa, 2009).

The soil application of mustard strains of Trichoderma T17 enriched FYM along with seed treatment recorded the maximum root and shoot length, maximum fresh weight of shoot and root of sunflower compared to control in addition to zero incidence of charcoal rot (Nagmani et al., 2011).
Effect of seed bioprimimg + soil application + foliar spraying with Trichoderma isolates on growth promotion of sorghum

The data presented in table 3 , shows the additive effect of biopriming of seed with different isolates of Trichoderma + soil application of Trichoderma isolates enriched FYM + foliar spraying with different isolates of Trichoderma significantly increased in on root length, shoot length and stem diameter of sorghum plants as compared to control

\section{Root length}

Maximum root length was recorded in T19 isolate $(53.248 \mathrm{~cm})$ however, T3 isolate $(53.124 \mathrm{~cm})$ was statistically at par with T19 followed by $\mathrm{T} 4(50.852 \mathrm{~cm})$ whereas least shoot length was found in untreated control $(36.288 \mathrm{~cm})$.

\section{Shoot length}

Maximum shoot length was recorded in T19 isolate $(326.200 \mathrm{~cm})$ however, T3 isolate $(324.800 \mathrm{~cm})$ was statistically at par with T19 followed by T4 $(306.800 \mathrm{~cm})$ whereas least 
shoot length was found in untreated control $(253.000 \mathrm{~cm})$.

\section{Stem diameter}

Maximum stem diameter was recorded in T3 isolate $(2.172 \mathrm{~cm})$ however, T19 isolate $(2.106 \mathrm{~cm})$ was statistically at par with T3 followed by $\mathrm{T} 15(1.712 \mathrm{~cm})$ whereas least shoot length was found in untreated control $(1.476 \mathrm{~cm})$.

The present study results are similar to that reported by Meena et al., (2008) on effect of foliar spray and biopriming of seed with Pseudomonas and Trichoderma on disease severity and plant growth against anthracnose of sorghum. Maximum increase in root length, shoot length and stem diameter and significant reduction in disease severity was observed. Singh and Singh (2008) also reported the effect of biopriming of seed and foliar spraying of Trichoderma harzianum isolates decreased the disease severity and increased overall plant growth and yield of sorghum. The combined effect of seed treatment and soil application with Trichoderma enriched FYM increased the root and shoot length and significantly reduced the wet root rot incidence in Chick pea as compared to control (Jambhulkar, 2015). The combination of soil application with PBP16G (Trichoderma viride) and seed treatment with Pusa 5SD (Trichoderma virens) showed the highest seed germination, root and shoot length and reduced wet root rot incidence in mung bean compared with any individual treatment (Dubey et al., 2011). The combination of seed treatment with Pusa 5SD (Trichoderma harzianum) and soil application with PBP4G (Trichoderma viride) plus carboxin increased the seed germination, root and shoot length and grain yield of chickpea and also reducing the Fusarium wilt incidence in chickpea rather than individual use of any treatment (Dubey et al., 2013). Jayalaxmi et al., (2013) conducted the study and concluded that combination of soil application of neem cake plus seed treatment plus soil application of Trichoderma viride followed by foliar spray of azadirachtin was found to increase the yield, host growth and reducing the diseases of sesame.

\section{References}

Abdel-Fattah, G. M., Shabana, Y. M., Ismail, A. E and Rashad, Y. M. 2007. Trichoderma harzianum: A biocontrol agent against Bipolaris oryzae. Mycopathologia. 164: 81-89.

Björkman, T., Price, H. C., Harman, G. E., Ballerstein, J and Nielsen, P. 1994. Improved performance of shrunken 2 sweet corn using Trichoderma harzianum as a bioprotectant. Hort. Science. 29: 471.

Chala, A., Tronsmo, A. M and Brurberg, M. B. 2011. Genetic differentiation and gene flow in Colletotrichum sublineolum in Ethiopia, the center of origin and diversity of sorghum, as revealed by AFLP analysis. Plant Pathol. 60:474-482.

Dubey, C.S., Tripathi, A and Singh, B (2013) Integrated management of Fusarium wilt by combined soil application and seed dressing formulations of Trichoderma species to increase grain yield of chickpea, Int. J. Pest Manag. 59(1): 4754.

Dubey, S.C., Bhavani, R and Singh B. 2011. Integration of soil application and seed treatment formulations of Trichoderma species for management of wet root rot of mungbean caused by Rhizoctonia solani. Pest Manage. Sci. 67:1163-1168.

Harman, G.E. 2000. Myths and dogmas of biocontrol: Changes in perceptions derived from research on Trichoderma harzianum T-22. Plant Dis. 84: 377-393.

Jambhulkar, P. P., Sharma, P and Meghwal, M. L. 2015. Additive effect of soil application with Trichoderma enriched FYM along with seed treatment and drenching with Trichoderma formulation 
for management of wet root rot caused by Rhizoctonia solani in chickpea. J. Pure Appl. Microbiol. 9: 405-412.

Jeyalakshmi, C., Rettinassababady, C and Nema, S. 2013. Integrated management of sesame diseases. J. Biopestic. 6(1):68-70.

Kleifeld, O and Chet, I. 1992. Trichoderma harzianum - interaction with plants and effect on growth response. Plant and Soil. 144: 267-272.

Mastouri, F and Harman, G. E. 2009. Beneficial microorganism Trichoderma harzianum induces tolerance to multiple environmental and physiological stresses during germination in seeds and seedlings. In: ISMPMI 2009 XIV Congress, Quebec, Canada.

Mathre D.E., Cook R.J and Callan N.W. 1999. From discovery to use: traversing the world of commercializing biocontrol agents for plant disease control. Plant Dis.83: 972-983.

Meena, K.Y., Singh, Y and Kharayat. 2012. Biological control of anthracnose of sorghum caused by Colletotrichum graminicola. Int. J. of Plant Protec. 2(5):33-338.

Mustafa, A., Khan, M.A., Inam-ul-Haq, M., Khan, S.H and Pervez, M.A. 2009. Mass multiplication of Trichoderma spp. on organic substrate and their effect in management of seed borne fungi. Pak. J. Phytopathol. 21(2):108-114.

Nagamani, P., Kumar, M. R and K. Sreedevi, K.2011.Evaluation of genetically mutated Trichoderma spp. for the management of Macrophomina phaseolina, incitant of charcoal rot of Sunflower. Curr. Bio. 4(4):434-441.

Naseby, D. C., Pascual, J. A and Lynch, J. M. 2000. Effect of biocontrol strains of
Trichoderma on plant growth, Pythium ultimum population, soil microbial communities and soil enzyme activities. J. Appl. Microbiol. 88:161- 169.

Ousley, M.A., Lynch, J.M and Whipps, J.M.1994. The effects of addition of Trichoderma inocula on flowering and shoot growth of bedding plants. Scientia Horticulturae. 59: 147-155.

Ozbay, N., Newman, S. E and Brown, W. M. 2004. The effect of the Trichoderma strains on the growth of tomato seedlings. Acta Horticulture. 635: 131-135.

Sharma, P., Patel, A.N., Saini, M.K and Deep, S. 2012. Field demonstration of Trichoderma harzianum as a plant growth promoter in wheat (Triticum aestivum $\mathrm{L}$ ). J. Agr. Sci. 4: 65- 73.

Singh, P.C and Nautiyal, C.S. 2012. A novel method to prepare concentrated conidial biomass formulation of Trichoderma harzianum for seed application. J. Appl. Microbiol.113:1442-1450.

Singh, Y and Singh, U.S. 2008. Bio-control agents for control of anthracnose in sorghum.J. Myco.Pl. Path.38 (3):448-491.

Yadav, S.K., Dave, A., Sarkar, A., Singh, H.B and Sharma, B.K. 2013. Coinoculated biopriming with Trichoderma, Pseudomonas and Rhizobium improves crop growth in Cicer arietinum and Phaseolus vulgari. Int. J. Agric. Biol. 6(2):255-259.

Zaidi, S., Usmani, S and Singh, B.R. 2006. Significance of Bacillus subtilis strain SJ101 as a bioinoculant for concurrent plant growth promotion and nickel accumulation in Brassica juncea. Chemosphere. 64:991-997.

\section{How to cite this article:}

Nazia Manzar and Yogendra Singh. 2019. Integration of Seed Biopriming, Soil and Foliar Application of Formulations of Trichoderma Species for Growth Promotion of Sorghum under Field Condition. Int.J.Curr.Microbiol.App.Sci. 8(06): 2648-2654. doi: https://doi.org/10.20546/ijcmas.2019.806.318 